Bulletin of the Section of Logic

Volume 46:1/2 (2017), pp. 1-10

http://dx.doi.org/10.18778/0138-0680.46.1.2.01

\title{
Professor Grzegorz Malinowski in Honorem
}

It is both an honor and a privilege for us to serve as Editors of this special issue of the Bulletin of the Section of Logic in honor of Professor Grzegorz Malinowski. Additionally, this is also Anniversary Issue of the Bulletin; it has been 45 years since the first issue of this Journal appeared. The anniversary provides an opportunity to look back and reflect on the past years. It also coincides with the 70th birthday of Professor Grzegorz Malinowski, Editor-in-Chief of the journal. On this occasion we would like to express our sincere gratitude for his efforts. The present volume, and the next one, are dedicated to Grzegorz Malinowski with best wishes of every success in his life.

Bulletin of the Section of Logic has been appearing since 1972. Ryszard Wójcicki, the Head of the Section of Logic of the Polish Academy of Sciences, launched the newsletter-journal designed for the exchange of scientific results among members of the Section with their national and international partners and cooperators. Jan Zygmunt was the editor of the first six issues of the Bulletin. In 1975, Grzegorz Malinowski takes on the responsibility of the Managing Editor. The year of 1992 was a very important moment in the history of the journal. In that year, the Department of Logic of Łódź University took over publication from the Polish Academy of Sciences and changed its publication policy into a regular peer-reviewed journal. Since then, Grzegorz Malinowski has been holding the position of Editor-in-Chief of the Bulletin of the Section of Logic.

Professor Grzegorz Malinowski, in full Grzegorz Marian Malinowski, was born in Łódź (Poland) on February 2nd, 1945. He studied mathematics at the University of Łódź, where he received his M.Sc. degree from the Faculty of Mathematics, Physics and Chemistry in 1968. Five years later, Grzegorz Malinowski received Doctor degree in Philosophy from the Institute of Philosophy and Sociology, Polish Academy of Sciences (for the algebraic interpretation of Łukasiewicz's logics). The dissertation was prepared under the supervision of Professor Ryszard Wójcicki. In 1979, Grzegorz 
Malinowski summarized his research results and published a book entitled Topics in the theory of strengthenings of sentential calculi which was the basis for his habilitation thesis submitted to the Institute of Philosophy and Sociology, Polish Academy of Sciences. In Poland, the habilitation is a prerequisite for eligibility for what are termed ordinary professorships. In 1992 Grzegorz Malinowski was awarded the Professor degree by the Former President of the Republic of Poland, Lech Wałęsa.

Professor Malinowski held many functions in numerous academic and scientific organisations; among other things, he was a Vice-Dean of the Faculty of Philosophy and History of Łódź University (from 1984 to 1987), Prorector for international relations at the University of Łódó, (1993-1996), Director of the Institute of Philosophy, Łódź University (2005-2012), Head of the Department of Logic and Methodology of Science, Łódź University (1991-2015). He was Editor-in-Chief of Folia Philosophica, Acta Universitatis Lodzensis, University of Eódź, (1987-2002), Editor of Logica Trianguli, University of Nantes (France), (1997-2002). Professor is a member of Scientific Commitees of the following journals: Agora (Universidad de Santiago de Compostela, Spain), since 1987; Epistemologiques (CNRS, Paris, France), since 1999; Studies in Grammar and Rhetoric (University of Białystok), since 1999. He has been cooperating with Studia Logica for many years: as an editor of the journal (from 1978 to 1987), Executive Editor (from 1991 to 1992), Associate Editor (1993-2003), and since 2004 as a member of the Advisory Board. He is also a member of the Editorial Board of the Studies in Universal Logic, Springer (A Birkhäuser book series), since 2007; and last but not least, Editor-in-Chief of the Bulletin of the Section of Logic,

Grzegorz Malinowski is the author of many books and articles that have appeared in international journals that make a significant contribution to logic (see Complete List of Publications for details). In particular, his investigations were concerned with many-valued logics, non-Fregean logics, paraconsistent logics, theory of consequence operations and its inferential generalizations. Among other things he developed an extensive theory of quasi-consequence operations and inferential many-valuedness. At the same time Grzegorz Malinowski was very active as a teacher. He had a number of courses and seminars, mostly devoted to several aspects of logic but also lectures on the aesthetics of jazz and seminars on Polish jazz, which were very popular among students. He was a supervisor of 8 doctor's theses of Marek Nowak, Piotr Łukowski, Janusz Kaczmarek, Janusz 
Maciaszek, Marek Rosiak, Andrzej Indrzejczak, Dorota Rybarkiewicz and Janusz Ciuciura. It is worth mentioning that all his promoted doctors are still continuing scientific research on logic and related fields.

The following two issues contain a number of papers covering a variety of topics and approaches to logic. Since a lot of scholars were interested in submitting their papers to the special issue, the editors decided to prepare two double issues instead of one. We are delighted that so many former students, friends and collaborators of Professor Malinowski from all over the World have contributed high quality manuscripts for these special issues. Thereby we would like to express sincere gratitude to all contributors and referees involved in this project for their great effort, kind cooperation and patience. We hope that this collection of valuable papers written by outstanding logicians will serve as an excellent tribute to Grzegorz.

\section{Complete List of Publications}

\section{Papers (from 1972 to 2014)}

[1] $N$-valued algebras of Eukasiewicz and their relations to Post algebras of order $N$ (in Polish), Zeszyty Naukowe Uniwersytetu Eódzkiego, Ser. I, 94 (1972), pp. 11-19.

[2] (with M. Spasowski) Dual counterparts of Eukasiewicz's sentential calculi (abstract), Bulletin of the Section of Logic, vol. 1 (1972), no. 3, pp. $2-7$.

[3] MV-algebras, Bulletin of the Section of Logic, vol. 2 (1973), no. 3, pp. $185-191$.

[4] (with M. Spasowski) Dual counterparts of Lukasiewcz's sentential calculi, Studia Logica, XXXIII (1974), no. 2, pp. 153-162; also in Selected papers on Łukasiewicz sentential calculi (ed. R. Wójcicki, G. Malinowski), Ossolineum 1977, pp. 161-170.

[5] S-algebras for n-valued sentential calculi of Eukasiewicz, Bulletin of the Section of Logic, vol. 3 (1974), no. 2, pp. 25-30; also (in Russian) [in:] Logiczeskij wyvod, Moskva, 1979, pp. 50-53.

[6] Degrees of maximality of some Lukasiewicz's logics, Bulletin of the Section of Logic, vol. 3 (1974), no. 3/4, pp. 27-33.

[7] S-algebras and the degrees of maximality for three and four valued logics of Eukasiewicz, Studia Logica, XXXIII (1974), no. 4, pp. 359-370. 
[8] Matrix representation for the dual counterparts of Eukasiewicz $n$-valued sentential calculi and the problem of their degrees of maximality (abstract), Bulletin of the Section of Logic, vol. 4 (1975), no. 1, pp. 26-32.

[9] Matrix representation for the dual counterparts of Eukasiewicz nvalued sentential calculi and the problem of their degrees of maximality, Proceedings of the V-th International Symposium on MultipleValued Logics, IEEE, Indiana University, Bloomington, USA, May 1975, pp. 252-261.

[10] Algebraic interpretation of Lukasiewicz logics (in Polish), Zeszyty Naukowe Uniwersytetu Łódzkiego, Folia Philosophica, Ser. I (1976), no. 9 , pp. 15-49.

[11] Degrees of maximality of Eukasiewicz-like sentential calculi (abstract), Bulletin of the Section of Logic, vol. 6 (1977), no. 2, pp. 74-81.

[12] S-algebras for n-valued sentential calculi of Eukasiewicz. The degrees of maximality of some Lukasiewicz's logics, [in:] Selected papers on Łukasiewicz sentential calculi (ed. R. Wójcicki, G. Malinowski), Ossolineum 1977, pp. 149-160.

[13] Historical Note. Bibliography of Eukasiewicz's logics, [in:] Selected papers on Łukasiewicz sentential calculi (ed. R. Wójcicki, G. Malinowski), Ossolineum 1977, pp. 177-199.

[14] Degrees of maximality of Eukasiewicz-like sentential calculi, Studia Logica, XXXVI (1977), no. 3, pp. 213-228.

[15] Classical characterization of n-valued Eukasiewicz sentential calculi, Reports on Mathematical Logic, 9 (1977), pp. 41-45.

[16] (with J. Zygmunt) Results in general theory of matrices for sentential calculi with applications to the Eukasiewicz logics, Zeszyty Naukowe Uniwersytetu Wrocławskiego, Prace Filozoficzne, XX (1978), pp. $43-57$.

[17] A proof of Ryszard Wójcicki's conjecture, Bulletin of the Section of Logic, vol. 7 (1978), pp. 20-25.

[18] Degrees of maximality of Eukasiewicz-like calculi (in Polish), Ruch Filozoficzny, XXXVI (1978), pp. 52-53.

[19] (with M. Michalczyk) Interpolation properties for a class of manyvalued propositional calculi, Bulletin of the Section of Logic, vol. 10 (1981), no. 1, pp. 9-16.

[20] The problem of degrees of maximality (A survey), Acta Universitatis Lodziensis, Folia Philosophica, Ser. I (1985), no. 9, pp. 37-57. 
[21] (with J-L. Gardies) D'un certain usage de la trivalence en logique deontique, Logique et Analyse, 94 (1981), pp. 179-199.

[22] (with M. Michalczyk) That SCI has the interpolation property, Studia Logica, XLI (1982), no. 4, pp. 375-380.

[23] Pseudo-referential matrix semantics for propositional logics, Bulletin of the Section of Logic, vol. 12 (1983), no. 3, pp. 90-98.

[24] Matrix referentiality, [in:] Frege Conference 1984, ed. G. Wechsung, Akademie-Verlag, Berlin 1984, pp. 148-161.

[25] Roman Suszko: A sketch of a portrait in logic, Studia Logica, XLIII (1984), no. 4, p. 315.

[26] Non-fregean logics and other formalizations of propositional identity, Bulletin of the Section of Logic, vol. 14, no. 1 (1985), pp. 21-29; also [in:] Essais on Philosophy and Logic, Proceedings of the XXXth Conference on the History of Logic, Cracow 1987, pp. 159-166.

[27] (with J. Czelakowski) Key notions of Tarski's methodology of deductive systems, Studia Logica, XLIV (1985), no. 4, pp. 321-351.

[28] Notes on sentential logic with identity, Logique et Analyse, 112 (1985), pp. 341-352.

[29] (with M. Michalczyk) Q-matrices and q-consequence operations, [in:] Abstracts of the 8th International Congress of Logic, Methodology and Philosophy of Science, Moscow, August 1987, pp. 252-254.

[30] (Janusz Maciaszek, co-autor) Metody GUHA generalizacji indukcyjnej (Wykłady GM w ramach IX Szkoły Logiki, Nieborów, 7-14 listopada 1986), Instytut Filozofii i Socjologii PAN, 1987, 59 pp.

[31] Sur les principes semantiques de Frege et sur une definition nonFregenne de la notion d'identite propositionnelle, [in:] Theorie de la definition (Actes de colloque de la Faculte de Philosophie de l'Universite Lyon III, Avril 1987), Math. Inf. Sci. hum., no. 116, 1991, pp. 57-62.

[32] Towards the notion of logical many-valuedness, Acta Universitatis Lodziensis, Folia Philosophica, 7 (1990), pp. 97-103.

[33] Shades of many-valuedness, Cahiers d'épistémologie, No. 9004 (1990), Université du Québec à Montréal, pp. 1-15.

[34] Q-consequence operation, Reports on Mathematical Logic, 24 (1990), pp. 49-59.

[35] Conjuntos borrosos y lógica de Zadeh, Agora, 9 (1990), Papeles de Filosofia, Universidad de Santiago de Compostela, pp. 67-74. 
[36] Inferential many-valuedness, abstract, Biuletyn Komisji Logiki. Towarzystwo Naukowe Warszawskie, 1 (1991), pp. 13-14.

[37] Inferential many-valuedness, [in:] Philosophical logic in Poland, J. Woleński (ed.), Synthese Library, Kluwer Academic Publishers, Dordrecht, 1994, pp. 74-84.

[38] Wielowartościowe matryce referencyjne [Many-valued referential matrices], VI Polski Zjazd Filozoficzny, Abstrakty, Uniwersytet Mikołaja Kopernika, Toruń, 1995, pp. 142-143.

[39] Many-valued referential matrices, Bulletin of the Section of Logic, vol. 24 (1995), no. 3, pp. 140-146.

[40] Helena Rasiowa - a view of the academic trajectory and the influence upon Polish and international scientific community, Proceedings of 26th International Symposium on Multiple-valued Logics, Santiago de Compostela, May 1996, pp. 144-146.

[41] Inferential extensions of Eukasiewicz modal logic (abstract), [in:] Łukasiewicz in Dublin, An international conference on the work of Jan Łukasiewicz, Department of Philosophy, University College Dublin, July 1996, 4 pp.

[42] Inferential extensions of Eukasiewicz modal logic, Bulletin of the Section of Logic, vol. 26 (1997), no. 4, pp. 220-224.

[43] On many-valuedness, sentential identity, inference and Eukasiewicz modalities, Logica Trianguli, no. 1 (1997), pp. 67-78.

[44] Modes of many-valuedness, [in:] C. Martinez, U. Rivas, L. VillegasForero (ed.), Truth in Perspective. Recent Issues in Logic, Representation and Ontology, Ashgate 1998, pp. 159-198.

[45] Referential and inferential many-valuedness, Mathesis Universalis, No. 6, Spring (1998), Foundation for Information Technology, Logic and Mathematics, www.calculemus.org (electronic publication, ISSN 1426-3513), $11 \mathrm{pp}$.

[46] Inferential paraconsistency, [in:] Paraconsistent Logic, Logical Philosophy, Mathematics \& Informatics (abstract of Stanisław Jaśkowski Memorial Symposium), Toruń 1998, pp. 77-82.

[47] Many-valued Post logic, [in:] Emil Post and the problem of mechanical provability. A Survey of Post's Contributions in the centenary of his birth, Studies in Logic, Grammar and Rhetoric 2(15), University of Białystok, Białystok 1998, pp. 45-54.

[48] Formalization of intensional functions and epistemic knowledge representation systems (abstract), 11th International Congress 
of Logic, Methodology and Philosophy of Science, August 20-26, 1999, Cracow, Poland, p. 127.

[49] Three-faces of many-valuedness (abstract), 11th International Congress of Logic, Methodology and Philosophy of Science, August 20-26, 1999, Cracow, Poland, p. 486.

[50] Formalization of intensional functions and epistemic knowledge representation systems, Logica Trianguli, no. 3 (1999), pp. 111-118.

[51] Referential and inferential many-valuedness, Abstracts of II World Congress on Paraconsistency, II Juquehy, Saõ Sebastião, Brazylia, 2000 .

[52] Logical Many-valuedness Versus Probability, Acta Universitatis Lodziensis, Folia Oeconomica 152 (2000), pp. 65-71.

[53] Suszko i wielowartościowość, [in:] M. Omyła (ed.), Idee logiczne Romana Suszko, Wydzia Filozofii i Socjologii Uniwersytetu Warszawskiego, Warszawa, 2001, pp. 151-160.

[54] Many-valued logics, Chapter 14 [in:] L.Goble (ed.), The Blackwell Guide to Philosophical Logic, Blackwell Publishers, Oxford, 2001, pp. 309-335.

[55] Lattice properties of a protologic inference, Studies in Logic, Grammar and Rhetoric 4 (17), (Language, Mind and Mathematics), 2001, pp. 51-58.

[56] Inferential paraconsistency, Logic and Logical Philosophy, 8 (2001), pp. 83-89.

[57] Many-Valued Logic, Chapter 34 [in:] D. Jacquette (ed.), A Companion to Philosophical Logic, Blackwell, 2002, pp. 545-561.

[58] Referential and inferential many-valuedness, [in:] W. A. Carnielli, M. E. Coniglio, I. M. Loffredo D'Ottaviano (eds), Paraconsistency the logical way to the inconsistent, Lecture Notes in Pure and Applied Mathematics, vol. 228, Marcel Dekker Inc., 2002, pp. 341-352.

[59] Inferential intensionality, Studia Logica, 76/1 (2004), pp. 3-16.

[60] Pro tretiu logiczeskuju ocenku [O trzeciej wartości logicznej], Filosofski Poszuk, XVI (2004), pp. 99-106.

[61] Teza Suszki a rozwój badań nad wielowartościowościg: czy każda logika jest dwuwartościowa?, [in:] J. Pelc (red.), Sens, Prawda, Wartość: Filozofia języka w dziełach Kazimierza Ajdukiewicza, Witolda Doroszewskiego, Tadeusza i Janiny Kotarbińskich, Romana Suszki, Władysława Tatarkiewicza, Biblioteka Myśli Semiotycznej, Polskie Towarzystwo Semiotyczne, Warszawa, 2006, pp. 243-252. 
[62] Tarski consequence and beyond, Foundational Issues in Logic: Logical Consequence and Logical Constants Revisited, 18-19 May 2006, Santiago de Compostela, 2006, pp. 1-14.

[63] That $p+q=c$ (onsequence), Bulletin of the Section of Logic, vol. 36 (2007), no. $1 / 2$, pp. $7-19$.

[64] Many-valued logic and its philosophy, [in:] Dov M. Gabbay and John Woods (eds), Handbook of the History of Logic, vol. 8 "The Many Valued and Nonmonotonic Turn in Logic", North-Holland, Amsterdam, Oxford, 2007, pp. 13-94.

[65] Fregean Axiom and many-valuedness, Bulletin of the Section of Logic, vol. 37 (2008), no. 3/4, pp. 245-252.

[66] A philosophy of many-valued logic. The third logical value and beyond, Chapter 5, [in:] S. Lapointe, J. Woleński, M. Marion, W. Miśkiewicz (eds), The Golden Age of Polish Philosophy, Logic, Epistemology, and the Unity of Science 16, Springer, 2009, pp. 81-92.

[67] Beyond three inferential values, Special Issue: Truth Values (ed. by Y. Shramko and H.Wansing), Studia Logica, 92/2 (2009), pp. 203-213.

[68] Concerning intuitions on many-valuedness, Bulletin of the Section of Logic, vol. 38 (2009), no. 3/4, pp. 111-121.

[69] Referentiality and matrix semantics, Studia Logica, 97/2 (2011), pp. 297-312.

[70] (with J. Woleński), Logic, formal methodology and semantics in works of Ryszard Wójcicki, Studia Logica, 99/1-3 (2011), pp. 7-30.

[71] Multiplying logical values, Logical Investigations, 18 (2012), Moscow - St. Petersburg, pp. 292-308.

[72] Identyczno i wielowartościowość, [in:] J. Golińska-Pilarek, A. Wójtowicz (red.), Identyczność znaku czy znak identyczności?, Wydawnictwa Uniwersytetu Warszawskiego, Warszawa, 2012, pp. 107-115.

[73] Identity, many-valuedness and referentiality, Logic and Logical Philosophy, 22/4 (2013), pp. 375-387.

[74] Kleene logic and inference, Bulletin of the Section of Logic, vol. 43 (2014), no. 1/2, pp. 43-52.

[75] Duality, paraconsistency and inferential logics, Trends in Logic XIII, Studia Logica International Conference, Short papers, University of Łódź, 2014, pp. 19-23.

[76] Eukasiewicz and his followers in many-valued logic, [in:] A. Garrido, U. Wybraniec-Skardowska (eds.), The Lvov-Warsaw School: Past and Present, 29 pp to appear. 


\section{Books}

[1] Selected papers on Łukasiewicz sentential calculi (ed. R. Wójcicki, G. Malinowski), Ossolineum 1977.

[2] Mordchaj Wajsberg, Logical works (ed. S. J. Surma; G. Malinowski - source editing), Ossolineum 1977.

[3] Formal methods in the methodology of empirical sciences (ed. M. Przełęcki, K. Szaniawski, R. Wójcicki, G. Malinowski - associate editor), Synthese Library, vol. 103, Kluwer, Dordrecht, 1977.

[4] Topics in the theory of strengthenings of sentential calculi, Institute of Philosophy and Sociology PAS, Warszawa 1979, 112 pp.

[5] Elementy logiki (komputerowo wspomagany kurs) [Elements of logic (a computer aided course)], RPBP III.24, Łódź 1989, $150 \mathrm{pp}$.

[6] Logiki wielowartościowe, Państwowe Wydawnictwo Naukowe, Warszawa 1990, 142 pp.

[7] Elements of logic, Fondation Philippe le Hodey, Brussels, 1990, 83 pp.

[8] Elements de logique, Fondation Philippe le Hodey, Brussels, 1993, 94 pp.

[9] Many-valued logics, Oxford Logic Guides 25, Clarendon Press, Oxford, 1993, $131 \mathrm{pp}$.

[10] Logiki wielowartościowe, Wydawnictwo Naukowe PWN, Warszawa 2006, 123 pp.

[11] Logika ogólna, Wydawnictwo Uniwersytetu Łódzkiego, Łódź 2007, 202 pp. (II edition), Wydawnictwo Uniwersytetu Łódzkiego, Łódź 2008.

[12] Logika ogólna, Wydawnictwo Naukowe PWN, Warszawa 2010, $200 \mathrm{pp}$.

\section{Selected Reviews}

[1] Gr. C. Moisil "Essais sur les logiques non-chrisippiennes", Bulletin of the Section of Logic, vol. 2 (1973), no.1, pp. 71-73.

[2] (with J.Zygmunt) R.Suszko "Abolition of the Fregean Axiom", Erkenntnis, 12 (1978), pp. 369-380.

[3] M. L. Dalla Chiara (ed.) "Italian Studies in the Philosophy of Science", Studia Logica. XLI (1982), no. 4, p. 432. 
[4] A. I. Arruda, N. C. da Costa, A. M. Sette (eds) "Proceedings of the Third Brasilian Conference on Mathematical Logic", Studia Logica, XLII (1983), no.4, pp. 483-484.

[5] Andrzej Pietruszczak, "Bezkwantyfikatorowy rachunek nazw. Systemy i ich teoria", Ruch Filozoficzny, XLIX:1 (1992), pp. 66-68.

[6] Gamut "Logic, Language and meaning", vol. I Introduction to logic, vol. II Intensional logic and logical grammar, The University of Chicago Press, Chicago and London, 1991, Studia Logica, 51:1 (1992), pp. 147-149

[7] R. Hähnle "Deduction in multiple-valued logics", Clarendon Press, Oxford, 1993, Notre Dame Journal of Formal Logic, 37:4 (1996), pp. 631646.

[8] Adam Nowaczyk "Gramatyka i prawda", Biblioteka Myśli Semiotycznej, Warszawa, 1999, Ruch Filozoficzny, Tom LVII, numer 3/4 (2000), pp. 520-523.

[9] Marek Nowak "Formalna reprezentacja pojęcia sạdu (dla zastosowań w teorii aktów mowy)", Wydawnictwo Uniwersytetu Łódzkiego, Łódź, 2003, Ruch Filozoficzny, Tom LX, numer 4 (2003), pp. 654-656.

[10] Wojciech Dzik "Unification types in logic", Wydawnictwo Uniwersytetu Śląskiego, Katowice, 2007, Ruch Filozoficzny, Tom LXV, nr 2 (2008), pp. 323-326.

Andrzej Indrzejczak and Janusz Ciuciura, Editors of the Special Issue 